Review

\title{
Autoantibodies in inflammatory arthritis
}

\author{
P. Conigliaro ${ }^{1}$, M.S. Chimenti ${ }^{1}$, P. Triggianese, F. Sunzini, L. Novelli, C. Perricone * ${ }^{*}$ R. Perricone \\ ${ }^{a}$ Rheumatology, Allergy and Clinical Immunology, Department of "Medicina dei Sistemi", University of Rome "Tor Vergata", Rome, Italy \\ b Reumatologia, Dipartimento di Medicina Interna e Specialità Mediche, Sapienza Università di Roma, viale del Policlinico 155, 00161 Rome, Italy
}

\section{A R T I C L E I N F O}

\section{Article history:}

Received 19 February 2016

Accepted 28 February 2016

Available online 9 March 2016

\begin{abstract}
A B S T R A C T
Rheumatoid arthritis (RA) is a systemic chronic inflammatory disease characterized by extensive synovitis resulting in erosions of articular cartilage and marginal bone with joint destruction. The lack of immunological tolerance in RA represents the first step toward the development of autoimmunity. Susceptible individuals, under the influence of environmental factors, such as tobacco smoke, and silica exposure, develop autoimmune phenomena that result in the presence of autoantibodies. HLA and non-HLA haplotypes play a major role in determining the development of specific autoantibodies differentiating anti-citrullinated antibodies (ACPA)-positive and negative RA patients. Rheumatoid factor (RF) and ACPA are the serological markers for RA, and during the preclinical immunological phase, autoantibody titers increase with a progressive spread of ACPA antigens repertoire. The presence of ACPA represents an independent risk factor for developing RA in patients with undifferentiated arthritis or arthralgia. Moreover, anti-CarP antibodies have been identified in patients with RA as well as in individuals before the onset of clinical symptoms of RA. Several autoantibodies mainly targeting post-translational modified proteins have been investigated as possible biomarkers to improve the early diagnosis, prognosis and response to therapy in RA patients. Psoriatic arthritis (PsA) is distinguished from RA by infrequent positivity for RF and ACPA, together with other distinctive clinical features. Actually, specific autoantibodies have not been described. Recently, anti-CarP antibodies have been reported in sera from PsA patients with active disease. Further investigations on autoantibodies showing high specificity and sensibility as well as relevant correlation with disease severity, progression, and response to therapy are awaited in inflammatory arthritides.
\end{abstract}

(C) 2016 Elsevier B.V. All rights reserved.

\section{Contents}

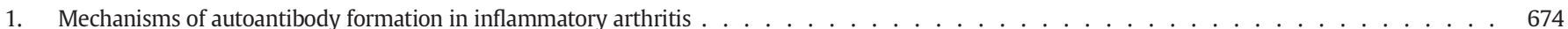

1.1. Genes implicated in autoantibody formation . . . . . . . . . . . . . . . . . . . . . . . . . . . . . 674

1.2. Environmental factors implicated in autoantibody formation . . . . . . . . . . . . . . . . . . . . . . . 674

2. Preclinical immunological phase in rheumatoid arthritis . . . . . . . . . . . . . . . . . . . . . . . . . . . . 675

3. Autoantibodies in undifferentiated arthritis . . . . . . . . . . . . . . . . . . . . . . . . . . . . 675

4. Autoantibodies in rheumatoid arthritis . . . . . . . . . . . . . . . . . . . . . . . . . . . . . . . . . . . . . . . . 675

4.1. Classical autoantibodies . . . . . . . . . . . . . . . . . . . . . . . . . . . . 675

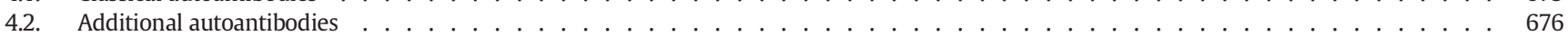

4.3. Autoantibodies are associated with disease outcome . . . . . . . . . . . . . . . . . . . . . . . . . 677

5. Autoantibodies in psoriatic arthritis . . . . . . . . . . . . . . . . . . . . . . . . . . 677

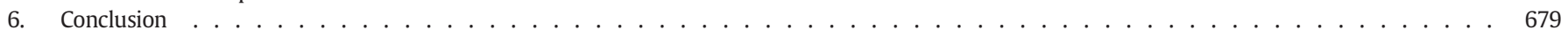

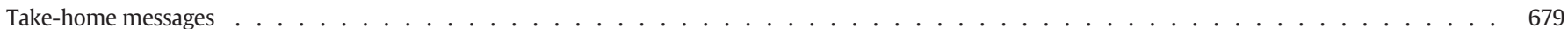

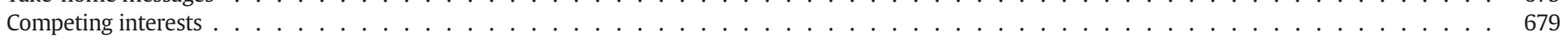

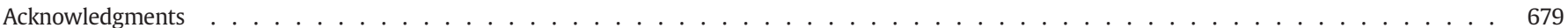

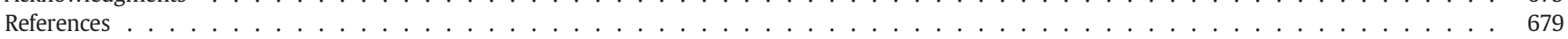

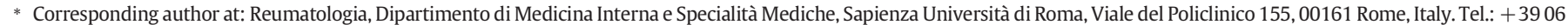
49974673; fax: + 390649974642.

E-mail address: carlo.perricone@gmail.com (C. Perricone).

1 These authors contributed equally to this paper. 


\section{Mechanisms of autoantibody formation in inflammatory arthritis}

Inflammatory arthritis is a group of rheumatologic conditions affecting approximately $3 \%$ of the adult population [1]. Rheumatoid arthritis (RA) is the most prevalent inflammatory chronic systemic disease characterized by extensive synovitis and an autoimmune response leading to cartilage and bone erosions with consequent joint destruction [2]. The loss of the immunological tolerance to self-antigens represents the first step toward the development of autoimmune phenomena. Susceptible individuals, under the influence of genetic and environmental factors, develop an underlying autoimmunity that manifests as the presence of autoantibodies [3]. (See Fig. 1.)

\subsection{Genes implicated in autoantibody formation}

It is well known that several genes contribute to the loss of tolerance. For instance, gene factors may affect antigen processing and presentation, lymphocyte proliferation and differentiation, and may encode for receptors of T and B cells [4]. HLA haplotypes still play a major role in determining the development of specific autoantibodies. In particular, in RA, the amino acid sequence QKRAA, QRRAA, or RRRAA at positions 70-74 of the DR $\beta 1$ chain, called "shared epitope" (SE), is associated with the production of anti-citrullinated antibodies (ACPA) and with the disease susceptibility [5-7]. Multiple alleles in the DRB1 gene share the SE such as HLA-DRB1*0401, *0404, *0405, *0408, *0101, ${ }^{*} 0102,{ }^{*} 1001$, and ${ }^{*} 1402$ [8]. Indeed, the conversion of arginine to citrulline at multiple pockets dramatically increases peptide affinity for DRB $1^{*} 0401$ and other SE alleles [9]. The increased peptide-MHC affinity leads to the activation of CD4 + T cells and can initiate an autoimmune response to citrullinated self-antigens in RA patients [10,11]. The peculiarity of the HLA-DRB1-SE is the association with a more severe disease characterized by early onset, rapid radiographic progression, and the presence of ACPA [12]. It has also been demonstrated that SE acts as a signal transduction ligand that binds to cell surface calreticulin and activates the NO-mediated oxidative signal in turn influencing the regulation of immunity $[13,14]$. The SE is also important in dendritic cells in which promotes the production of IL-6 and IL-23, activating and expanding Th17 cells [15]. The SE can also directly enhance the differentiation of Th17 cells expressing the receptor activator for NF$\kappa B$ ligand [16]. Very recently, a protective role for the development of ACPA in RA has been identified for the HLA-DRB1*13 alleles; indeed, patients with the HLA-DRB1*13 have lower ACPA levels and decreased citrullinated epitope recognition [17]. Seronegative and seropositive RA can also be distinguished by non-HLA genes [18]. For instance, the second most important genetic association in Caucasian population is in the gene protein tyrosine phosphatase non-receptor type 22 (PTPN22) encoding a tyrosine phosphatase, Lyp, a powerful inhibitor of $\mathrm{T}$ cell activation. It has been hypothesized that the diseaseassociated allele would produce a protein affecting the threshold for $\mathrm{B}$ and T cell receptor signaling [19]. The single nucleotide polymorphism in PTPN22 increases the risk of RA by 40-80\% (OR 1.4-1.8) [20-22]. In contrast, in the Asian population, the most important genetic association is with the peptidylarginine deiminases citrullinatin isoenzyme 4 (PADI4) gene [23,24]. PADI4 is one of several isoenzymes carrying the post-translational conversion of arginine residues to citrulline, and this may be related to the production of ACPA [25]. ACPA-positive and ACPA-negative patients have partial genetic overlap, but evidences supporting a different genetic risk profile are increasing, suggesting that not only from a genetic perspective but also from pathogenic and clinical perspective, ACPA-positive and ACPA-negative represent two forms of RA [26-28]. For ACPA-negative disease, HLA-DRB1*03 and the gene interferon regulatory factor 5 seem to predispose to ACPAnegative RA [29-35]. Recently, Viatte et al. have confirmed the results from the Rheumatoid Arthritis Consortium International evidencing known markers, including ANKRD55 (a gene of unknown function), and identifying new and specific markers of anti-CCP negative RA, such as prolactin and NFIA [36].

\subsection{Environmental factors implicated in autoantibody formation}

Data gathered from the literature point at an interaction with environmental factors, which seems necessary for the development of inflammatory arthritides. The risk factors suggested so far include diet, coffee intake, alcohol, and body mass index [37]. Cigarette smoking is the only risk factor clearly associated with disease susceptibility. Smoke has several detrimental arrows including complement activation

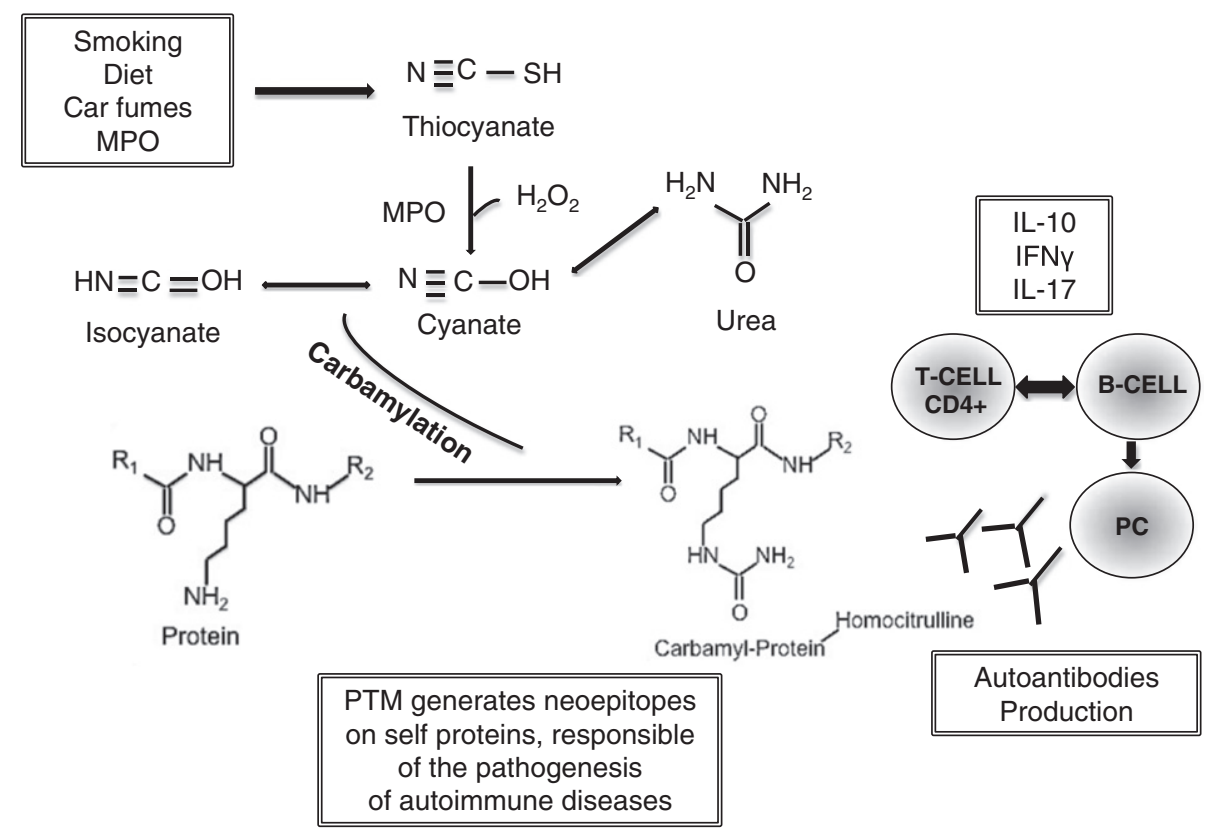

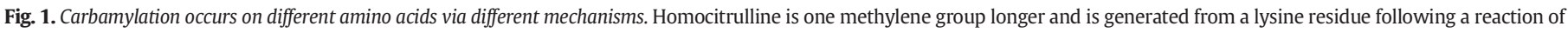

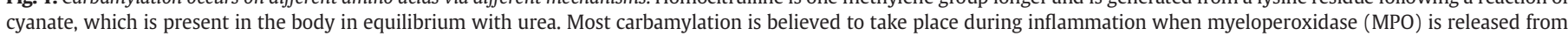
neutrophils. MPO converts thiocyanate to cyanate, now allowing more carbamylation to occur. PTM: post-translational modification; PC: plasmacells. 
in vitro, induction of pro-inflammatory IL- $1 \alpha$, IL-1 $1 \beta$, IL-6, and IL-8 and changes in gene expressions with a significant up-regulation of the heat-shock proteins in synovial fibroblasts [38-41]. Of interest, the association is true for ACPA-positive RA rather than ACPA-negative RA patients [42]. The number of the SE copies further modifies the risk. Smokers who do not carry the SE have a 1.5-fold elevated risk of developing ACPA and RA compared with non-smokers who do not carry the SE. This risk increases to 21-fold in smokers carrying two copies of the SE. Moreover, smoking increases the proportion of citrulline-positive cells in the lungs [43]. These findings suggested that smoking triggers citrullination in lungs through activation of PAD providing a substrate for the immune activation [43]. Carbamylation is a process similar to citrullination but the main difference concerns the modification of lysine instead of arginine [44]. Effects of carbamylation on proteins include changing of their polymerization ability, sensitivity to proteinases, and antibody antigen binding avidity $[45,46]$. Most of the carbamylation process is believed to take place during inflammation when myeloperoxidase (MPO) is released from neutrophils indicating that MPO released from neutrophils can further increase the level of carbamylation during inflammation [47,44]. Consequences of carbamylation have been reported to occur at the protein, cellular, and systemic level [48]. Anti-CarP antibodies have been identified in patients with RA and in individuals before the onset of clinical symptoms of RA [44,49]. The presence of anti-CarP antibodies in RA patients did not show significant associations with genetic risk factors (HLADRB1 alleles and PTPN22) and smoking suggesting that different biological mechanisms may be involved in the formation of anti-CarP and anti-CCP antibodies [50]. Another environmental risk factor identified in RA is the notorious Porphyromonas (P.) Gingivalis, the only bacterium known so far of containing the enzyme PAD involved in citrullination of both bacterial and human proteins such as arginine in fibrin in periodontal tissue $[51,52]$. RA is prevalent in individuals with chronic periodontitis [53]. Therefore, $P$. gingivalis can potentially contribute to the generation of de novo epitopes that may trigger the formation of autoantibodies. Contradictory data have been published regarding the correlation between the levels of antibodies against $P$. gingivalis and ACPA in RA patients [51,54,55]. ACPA might be produced outside the joint in the mucosal sites such as lung and gingiva. As a consequence, ACPA might cross-react through molecular mimicry with citrullinated epitopes in the joint initiating an inflammatory response in genetically susceptible individuals. Other substances may be associated with a higher risk of developing ACPA-positive RA, such as silica [56], especially in tobacco smokers. Silica exposure has been linked with the development of autoimmunity in several contests, probably associated with an alteration of Fas-mediated apoptosis in T lymphocytes [57].

\section{Preclinical immunological phase in rheumatoid arthritis}

The identification of patients in a preclinical phase may lead to an early diagnosis and a prompt treatment with better disease outcomes. Recent studies have demonstrated the presence of both rheumatoid factor (RF) and ACPA up to 10 years before the onset of RA in the so-called "pre-articular or lymphoid phase" of the disease [58-61]. The autoantibody titers increase as the onset of disease approach together with a progressive increase of ACPA antigens repertoire, known as epitope spreading [62]. Indeed, ACPA reactivity against characteristic specificities, in particular $\alpha$-enolase, fibrinogen $\beta 36-52$ and $\beta 74$, and filaggrin seem to increase before disease onset in asymptomatic individuals [63]. This immunologic phenomenon has also been associated with a higher risk of progression to RA $[64,65]$. All together, these data suggested that the adaptive immune response against autoantigens is initiated years before the clinical signs of the disease. Likewise, in certain murine models of arthritis, it has been observed an increase in antibody levels before the onset of clinical symptoms or before the relapse of arthritis $[66,67]$. Recently, anti-CarP antibodies were detected in mice with collagen-induced arthritis (CIA) and appeared after immunization, which caused local inflammation, combined with the notion that inflammation can induce carbamylation and lead to a break of B cell tolerance to carbamylated proteins [66]. Furthermore, in a model of chronic antigen-mediated polyarthritis the production of ACPA, RF, and anti-type II collagen (CII) antibodies was observed in the absence of clinical signs of arthritis and increased before the relapse of arthritis [67].

\section{Autoantibodies in undifferentiated arthritis}

The term "undifferentiated arthritis" is used to describe those patients with early inflammatory arthritis during the first weeks to months following symptom onset, where it is not possible to establish a specific diagnosis. Many of these patients reach spontaneous remission without need to take a chance to adverse effect of treatment while others will eventually be diagnosed with RA after further evolution of the symptoms and findings [68]. In this contest, it is essential to recognize those patients with undifferentiated arthritis and positive predictive factors of RA development. ACPA-positive patients with undifferentiated arthritis have a chance of $90 \%$ to progress to full-blown RA within 3 years [69]. Indeed, ACPA represents an independent risk factor for developing RA in patients with undifferentiated arthritis or arthralgia [64,70,71]. Moreover, also the titer of ACPA in patients with arthralgia seems to predict future arthritis [72,73]. The ACPA isotype switching to IgG, IgA, IgM, or IgE occurs before disease onset in undifferentiated arthritis, without further changes after diagnosis [61]. In a recent large cohort study of subjects with general musculoskeletal symptoms ( $\mathrm{n}=2028$ ), anti-CCP positivity was associated with a risk rate (RR) of 36.8 for a diagnosis of inflammatory arthritis and an RR of 50.4 for a diagnosis of RA. The sensitivity and specificity of anti-CCP for the diagnosis of inflammatory arthritis were $57.4 \%$ and $98.1 \%$, respectively, while they increased to $64.9 \%$ and $97.9 \%$ for the diagnosis of RA [74]. Recently, also anti-CarP antibodies have been associated with the risk of developing RA (hazard ratio 1.56) in 340 patients with arthralgia during a median follow-up period of 3 years independently to anti-CCP antibody positivity [75]. Furthermore, the levels of anti-CarP antibodies were higher in individuals who subsequently developed RA compared with controls, and their concentration and frequency increased gradually after the disease onset. The sensitivity of anti-CarP antibodies was $13.9 \%$ in pre-symptomatic individuals and increased to $42.2 \%$ after the development of RA [76]. Indeed, current hypothesis suggests that these antibodies could be involved in the pathogenesis of RA since they appear several years before RF appearance and before the diagnosis of RA, similarly to what occurs for ACPA $[49,72,77]$. However, anti-CarP antibodies have been also detected in other forms of non-RA early arthritis such as in juvenile idiopathic arthritis (16.7\%), reactive arthritis (16\%), spondyloarthritis (15\%) or psoriatic arthritis (9\%) $[78,79]$. Further investigations are needed to shed more light on the presence of anti-CarP antibodies in other autoimmune/inflammatory arthritis different from RA.

\section{Autoantibodies in rheumatoid arthritis}

\subsection{Classical autoantibodies}

RF and ACPA are well-known serological markers for RA diagnosis according to the 2010 American College of Rheumatology (ACR)/ European League Against Rheumatism (EULAR) classification criteria [80]. RF is present in about $50-80 \%$ of patients affected by RA. It has a moderate specificity, around $66 \%$, as it is detected in other autoimmune diseases, systemic infections, and in up to $10 \%$ of healthy subjects [81]. Nevertheless, many differences exist between RF in health and disease. The former is an IgM produced by B1 cells as "natural" antibody that shows low affinity and polyreactivity, the last undergoes isotype switching and somatic hypermutation as consequence of B cells 
receiving help from $\mathrm{T}$ cells [82]. The lack of high specificity of RF has stimulated the research of other autoantibodies more specific for the diagnosis of RA. The identification of ACPA led to relevant and novel insights into RA diagnosis and etiopathology. Indeed, RA constitutes at least two clinical syndromes, ACPA-positive and ACPA-negative $\mathrm{RA}$, that share many clinical features, but differ with respect to genetic background, predisposing environmental factors and clinical progression/remission $[30,69,83,84]$. ACPA recognize a variety of posttranslational modified proteins generated from the enzymatic reaction catalyzed by PAD, such as filaggrin, fibrinogen, vimentin, type II and type I collagen, alpha enolase, heat-shock protein-90, and many others (Table 1). Citrullination is the critical step for the recognition of the different proteins, highly expressed in the synovial membrane during inflammation, by ACPA [85]. Interestingly, PAD enzymes were found in monocytes (PADI4) and macrophages (PADI2 and PADI4) in synovial fluid suggesting that citrullination may take place locally in the joint and B cells secreting ACPA have been detected in synovial fluid from RA patients [2,86-88]. Another observation that strongly supports the role of ACPA in RA pathogenesis comes from genetic studies such as the associations, abovementioned, with the gene encoding PADI4 or with HLA-DRB1 genes [25,69]. These autoantibodies show high specificity (98\%), sensitivity comparable with $\mathrm{RF}$ (68\%) [89]. There are different assays for measuring ACPA, the widely used are based on cyclic citrullinated peptides (CCP), both second-generation (CCP2) (patients peptide libraries) or third-generation CCP (CCP3) (combinatorial peptide libraries) $[70,90,91]$. There is no evidence so far that testing ACPA fine specificities may improve specificity and sensitivity of anti-CCP assays, although they could be important for understanding disease progression [65,92].

\subsection{Additional autoantibodies}

Other autoantibodies have been studied in RA and suggested as possible biomarkers, when considered alone or in combination, to improve diagnosis, prognosis, and response to therapy [93]. Most of them can be recognized by ACPA being part of this subgroup of autoantibodies (refer to Table 1). Anti-Ra33 antibodies (directed against an antigen of $33 \mathrm{kDa}$ ) recognize both unmodified and citrullinated heterogeneous nuclear protein (hnRNP) A2/B1, proteins present in spliceosome. They have been described in approximately $36 \%$ of patients affected by RA and they showed a high specificity (90-96\%) and a low sensitivity (32\%) [94,95]. Anti-Ra33 antibodies have been associated with early arthritis and also with a mild disease leaving a possible space as a prognostic marker [96]. In a recent study, Konig et al. identified three subgroups of RA patients; the first one who presented antibodies against citrullinated Ra33 with long-lasting disease and erosive pattern, those anti-native Ra33-positive, entirely in early phases and with minimal erosions, and lastly, patients positive for both native and citrullinated Ra33 that showed rapidly progressive disease [97]. Anti-mutated citrullinated vimentin (MCV) antibodies bind a mutated and citrullinated vimentin expressed in synovial tissues. The mutations occurring in vimentin (glycine to arginine) increase antigenicity and diagnostic value compared with anti-citrullinated vimentin antibodies, also known as anti-Sa antibodies [98]. In early RA, anti-MCV sensitivity and specificity (64\% and 97\%) are higher than those of RF [99]. A recent meta-analysis, which included a total of 12 studies and 2003 RA patients, demonstrated a higher sensitivity of anti-MCV (68.6\%) than anti-CCP $(61.7 \%)$ in the diagnosis of RA, although anti-MCV specificity (94.2\%) remained lower than that of anti-CCP (97.1\%) [100]. High levels of anti-MCV antibodies seem to predict a rapid erosive disease in early RA and have been associated with active disease and worst outcomes [101,102]. Anti-malondialdehyde (MDA) and anti-malondialdehyde acetaldehyde (MAA) antibodies are the result of post-translational modifications such as the lipid peroxidation [93]. Antibodies against MDA adducts, especially MDA-LDL, have been identified in RA patients and associated with cardiovascular disease as myocardial infarction [103]. A recent study demonstrated the presence of both MAA adducts and anti-MAA adducts in RA patients suggesting that these are more stable than MDA adducts and more likely to be present in vivo [104]. Furthermore, a positive correlation was observed between anti-MAA antibodies and the presence of ACPA revealed by multiplex antigen array [104]. However, anti-MAA antibodies are not very specific and not suitable for diagnostic purpose since they have been detected also in patients affected by alcohol-induced hepatitis or cirrhosis and type 2 diabetes $[105,106]$. Antibodies anti-PAD4 have been identified in $22-45 \%$ of RA patients and they show a specificity that is lower than $50 \%$ [107-109]. A specific group of anti-PAD4 antibodies cross-reacts with PAD3 and anti-PAD3 antibodies were detected in 12-18\% of RA patients [110]. Patients with the cross-reactive PAD3/PAD4 antibodies seem to display an aggressive RA in terms of radiographic joint damage and progression of the disease [110]. BRAF, a serine-threonine kinase involved in the MAPK pathway, has been identified in RA by a proteomic approach aimed at the identification of autoantigens [109]. Anti-BRAF antibodies have been detected in $21-32 \%$ of RA patients $[109,111]$. However, anti-BRAF antibodies display a low specificity since they were detected also in systemic lupus erythematosus (SLE) and Sjogren's syndrome in almost similar percentages [93].

Anti-CII antibodies have been detected in about $30 \%$ of RA patients and they show a low specificity since they were detected also in other autoimmune diseases such as SLE, systemic sclerosis, and recurrent polychondritis. Anti-CII antibodies recognize different epitopes in human RA and murine models of arthritis, some of them shared between the different species including citrullinated-CII, C1, and U1 epitope [112]. High titers of anti-CII antibodies in RA synovial fluid and $\mathrm{B}$ cells producing anti-CII antibodies in RA synovia were reported $[114,115]$. Moreover, it has been demonstrated that serum and synovial titers of anti-CII IgG correlate with levels of acute phase proteins and pro-inflammatory cytokines, as TNF- $\alpha$ and IL-6 [116]. Immune-

Table 1

Anti-citrullinated protein antibodies in sera of patients with rheumatoid arthritis.

\begin{tabular}{|c|c|c|c|c|c|}
\hline Antigen & Sensitivity (\%) & Specificity (\%) & Assay & Correlation & References \\
\hline Keratine & $36-59$ & $88-99$ & ELISA & Early disease & [1] \\
\hline Filaggrin & 76 & 96 & ELISA CCP-1 & Unknown & {$[2,3]$} \\
\hline CCP-patients peptide libraries & 75.4 & $94.4-99$ & ELISA CCP-2 & Severity and erosive disease & {$[4]$} \\
\hline CCP-combinatorial peptide libraries & $75-81.6$ & $92-96.8$ & ELISA CCP-3 & Early disease & {$[5,6]$} \\
\hline Fibrinogen/fibrin & $60.9-83$ & $95-98.7$ & Immuno blotting & Unknown & {$[7,8]$} \\
\hline Vimentin & 47 & 98 & Immuno blotting & Severity and erosive disease & {$[9-11]$} \\
\hline MCV & $64-82$ & $97-98$ & ELISA & Severity and rapid erosive disease & {$[11-14]$} \\
\hline Collagen type II & 41 & 94 & ELISA & Early acute inflammation and early radiographic damage & {$[15-17]$} \\
\hline Collagen type I & 32 & 99 & ELISA & Unknown & {$[18]$} \\
\hline alpha-enolase & $37-62$ & 98 & ELISA & Unknown & [19] \\
\hline $\mathrm{BiP}$ & 95 & Not known & Immuno blotting & Unknown & [23] \\
\hline HSP-90 & 29 & 96 & ELISA & Interstitial lung disease & {$[24]$} \\
\hline
\end{tabular}

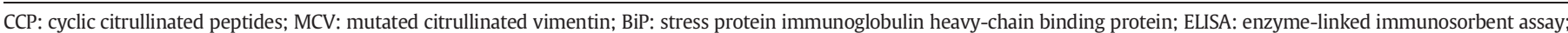
HSP-90: heat-shock protein-90. 
complexes containing anti-CII were detected in human RA sera and could induce cytokine production such as TNF- $\alpha$, IL-1 $\beta$, CXCL8 via Fc $\gamma$ receptor Ila expressed on macrophages [117]. Antibodies against the stress protein immunoglobulin heavy-chain binding protein (BiP), in the native and citrullinated forms, are found in $64-72 \%$ of RA patients and display a specificity of $71 \%$ and a sensitivity of $73 \%[118,119]$. They have been implicated in the pathogenesis of RA since BiP was found to stimulate synovial T-cell and polymorphonuclear cell proliferation [120,121]. Anti-CarP antibodies have been extensively described in RA patients. These antibodies are a family different from ACPA that were identified for the first time in $35-45 \%$ of RA patients, mostly in ACPA-positive patients (49-74\%), but also in ACPA-negative patients (16-30\%) [122,123]. Inhibition studies confirmed that these antibodies overlapped only partially with the occurrence of ACPA [123]. In a recent study anti-CarP antibodies demonstrated in early arthritis a sensitivity of $44 \%$ and a specificity of $89 \%$, both lower than those of anti-CCP and $\mathrm{RF}$ [78]. Therefore, anti-CarP antibodies could be useful for early diagnosis especially in ACPA-negative patients and for identifying patients that require an aggressive treatment [76,124]. How anti-CarP antibodies would contribute to arthritis is unknown but may involve immune complex formation between anti-CarP antibodies and carbamylated proteins in the joint.

\subsection{Autoantibodies are associated with disease outcome}

Autoantibodies have been largely investigated in order to establish serological markers able to early confirm clinical diagnosis of RA and to predict disease evolution [2].

High RF serum levels have been associated with an aggressive articular disease, extra-articular manifestations, and a worse outcome $[125,126]$. Likewise, ACPA have been associated with disease severity, radiological progression of the disease, disability, and increased mortality in RA [83,127-131]. The combination of ACPA and RF positivity correlates with a more severe and erosive disease and they associate with a worse disease outcome when compared with seronegative RA [132]. RF seems to enhance the pathological effects of ACPA through preferential binding to ACPA and potentiation of the subsequent immune response. Moreover, the course of ACPA-positive disease seems to be characterized by more persistent inflammation than its ACPA-negative counterpart [133]. Similar results were obtained in patients with undifferentiated arthritis where the presence of ACPA seems to predict more joint damage, progression to RA, and severe disease resulting in poor prognosis compared to ACPA-negative patients [64,83,134-136]. However, despite the fact that almost $40 \%$ of RA patients are ACPA negative, aggressive disease and severe radiologic progression can be present. For these reasons, new biomarkers are needed for early diagnosis and prognosis $[58,91]$. The presence of anti-CarP antibodies in ACPAnegative RA patients has been associated with increased disease activity and severe joint damage [123]. Comparable to ACPA, anti-CarP antibodies are independently associated with increased joint damage at the baseline of RA diagnosis [76]. Recently, anti-CarP antibodies have been associated in a large cohort of patients with inflammatory arthritides $(\mathrm{n}=1995)$ with increased disability and higher disease activity [137]. Therefore, anti-CarP antibodies may be a useful biomarker to identify ACPA-negative patients who might evolve in RA and newly diagnosed RA patients who would require prompt and aggressive treatment [44]. Nonetheless, their significance in RA is still under investigation. For instance, Alessandri et al. found that anti-CarP can be detected in up to $9.2 \%$ of healthy first-degree relatives of patients with RA, a similar prevalence than anti-CCP and RF. Besides, it is not known whether these subjects will develop RA, it should be underlined that these autoantibodies did not correlate with anti-CCP neither with RF [138]. Anti-MCV antibodies have been demonstrated to perform better than ACPA as predictor of radiographic damage; conversely, its additional diagnostic and prognostic role in comparison to ACPA in both early and established RA is controversial [139]. Some authors found that anti-MCV might identify a subset of RA patients with aggressive early erosive disease [140]. Recently published ESPOIR cohort study compared the ability of ACPA, against anti-MCV antibodies and citrullinated fibrinogen to predict 1-year rapid radiographic progression in early RA, and suggested that anti-MCV antibodies can be more discriminant to predict radiographic progression risk [101]. Anti-CII antibodies seem to characterize an early inflammatory/destructive phenotype, in contrast to the late appearance of an inflammatory/destructive phenotype in ACPA-positive RA patients [141]. Anti-CII antibodies have been associated with increased radiographic damage at the time of diagnosis in a prospective cohort of early RA patients [141].

Autoantibody presence also seems to correlate with extra-articular clinical manifestations, such as the heart involvement. It is well reported that RA is an independent risk factor for cardiovascular events, which cause up to $40 \%$ of deaths in these patients [142,143]. Lopez-Longo et al. investigated the association between ACPA and ischemic heart disease in RA patients, and they found that ACPA presence is independently associated with the development of ischemic heart disease that is irrespective of the titers of autoantibodies [144]. The presence of autoantibodies characterize RA phenotype not only in terms of outcome but also in terms of clinical intervention [133]. Stratifying patients with undifferentiated arthritis or RA on ACPA presence led to the identification of more homogenous patient groups in terms of both disease course and response to treatment. Evidence from the literature suggested that low/intermediate pretreatment levels of ACPA were associated with a more favorable response to methotrexate treatment in recent-onset ACPA-positive arthritis, whereas high levels were associated with an insufficient response [145]. Likewise, in another study, methotrexate postponed RA diagnosis and retarded radiographic joint damage in ACPA-positive patients compared with undifferentiated ACPA-negative patients [146]. The BeSt study described that RA ACPApositive patients treated only with DMARDS undergo greater joint destruction, while no difference in radiographic progression in RA ACPA-positive and RA ACPA-negative patients with combination therapy occurred [147]. More recently, 2-year results from the AMPLE trial investigated the impact of baseline ACPA concentration on efficacy outcomes following treatment with subcutaneous abatacept or adalimumab. In both treatment groups, ACPA-negative patients responded worse than antibody-positive patients. Patients with the highest baseline ACPA concentrations had a better clinical response to abatacept than patients with lower concentrations had. Such observation was not found in the adalimumab treated group [148]. Moreover, Gardette et al. investigated whether serum anti-CCP antibody could predict a good response to rituximab (RTX) in RA patients [149]. In this study, 114 RA patients were evaluated for a primary end point (decrease in DAS28 > 1.2 at 6 months) and secondary efficacy criteria including a good response and remission according to EULAR criteria. In accordance with this study, high anti-CCP antibody levels were associated with good response together with trend for remission [149].

\section{Autoantibodies in psoriatic arthritis}

Psoriatic arthritis (PsA) is a chronic inflammatory arthropathy seronegative for RF, and associated with psoriasis [150]. PsA is classified among the SpA group because it shares with SpA several clinical manifestations as peripheral and axial joints involvement (arthritis, spondylitis, and sacro-ileitis), skin and nail diseases, dactylitis and enthesitis [151]. The overall prevalence of PsA has been reported to range from $0.01 \%$ (95\% CI $0.00-0.17$ ) in the Middle East to $0.19 \%$ (95\% CI 0/16-0.32) in Europe [152]. Peripheral joint involvement is a potentially debilitating feature of PsA: it is commonly symmetrical and polyarticular that often affects distal interphalangeal joints distinguishing PsA from RA [153]. Characteristic extra-articular manifestations of PsA include psoriasis, nail psoriasis, uveitis, and inflammatory bowel disease (IBD), that may be frequently unrecognized or undertreated [154]. The extra-articular concomitant diseases, also 
called comorbidities, such as obesity, dyslipidemia, type II diabetes, liver disease, and cardiovascular disease, are reported to be increased in patients with PsA, and their role in the progression and clinical response to treatment remains under investigations [154-157]. The Group for Research and Assessment of Psoriasis and Psoriatic Arthritis (GRAPPA) developed and recently updated the treatment recommendations for the key manifestations of PsA, including related comorbidities [158]. The development of the Classification Criteria for Psoriatic Arthritis (CASPAR) facilitates clinicians in the classification of PsA [159]. Among the several classification criteria that have been published, CASPAR criteria result to be simple and easy to use and show high sensitivity by introducing the family history of psoriasis [160]. Medical history, physical examination, blood tests, and imaging (radiography, ultrasound, and magnetic resonance) of the joints are used for diagnostic purposes [161]. The diagnosis of PsA is thus mainly clinical and diagnostic biomarkers are not yet available. Enthesitis seems to be the primum movens of the disease, as well as the prominent clinical feature at presentation in up to $38 \%$ of PsA patients [162]. Monocyte-derived cytokines, as myeloid-related protein (S100A8/A9), seem to play a role in the propagation and perpetuation of the inflammatory process in patients with psoriasis and PsA, because of an activated monocyte/ macrophage system involved in the "enthesal-complex" [163]. Evidence from the literature suggests that autoimmune processes may drive features of PsA [164]. Autoimmunity, in PsA pathogenesis, has been suggested by the presence of lymphoid aggregates in synovial tissues [165]. Histologically, PsA is characterized by lining layer hyperplasia, B and T lymphocytes' infiltrates, innate immune cells' activation, and joint vascular remodeling and angiogenesis [165]. We previously reported an abnormal distribution of peripheral blood $B$ cell in both RA and PsA patients suggesting a role of B cells in PsA pathogenesis [166]. An autoimmune model describing potential autoantigens in the skin and joints of PsA patients has not been identified so far [151]. PsA is distinguished from RA by infrequent positivity for RF and ACPA, together with other distinctive clinical features [167,168]. Few studies looked for ACPA in PsA patients and found far lower prevalence compared to patients with RA (Table 2). However, authors described that presence of ACPA was significantly correlated with polyarticular involvement (often symmetric), presence of erosions, and presence of the shared epitope [169]. Prevalence and prognostic value of ACPA in PsA remain debated [170-175]. Detection of antinuclear antibodies (ANA) was recently reported as more frequent in sera from PsA patients than in those from controls suggesting that ANA could be a diagnosis orientation tool in autoimmune arthropathies [176]. TNF- $\alpha$ antagonists commonly used for treatment of moderate-to-severe psoriasis and PsA have been associated with induction of autoantibodies in PsA patients [177-179]. Recently, it has been described that routine autoantibodies monitoring in RA and PsA patients do not represent useful tool to predict the development of anti-adalimumab antibodies [180]. Indeed anti-adalimumab antibodies have been proposed as an early marker associated to a poor clinical response to the treatment [180]. Specific anti-PsA peptide antibodies were described in PsA patients and only in a small proportion of patients with psoriasis without PsA, suggesting that they could be specific for PsA [181]. Anti-PsA peptide antibodies target peptide epitopes expressed in skin proteins (fibrillin, desmocollin, and keratin) and in N-RAP, highly expressed within the entheses [181]. Moreover, these autoantibodies bind the Toll-like receptors (TLR)2 that play critical roles in the activation of innate immunity contributing to autoimmunity [181]. More recently, authors reported a gene array analysis of paired synovial membranes and peripheral blood cells in patients with PsA. They identified the modulation of cluster of genes encoding for molecules involved in cell migration and tissue invasion, in neoangiogenesis, in the process of bone formation, and in a $\mathrm{T}$ cell immune response with prevalent up-regulation of several Th17-related genes [182]. Anti-CarP antibodies were reported in sera from PsA patients with active disease in the absence of RF and/or ACPA specificities [151]. In accordance with such evidence, the measurement of anti-CarP antibodies shows a good

Table 2

Prevalence of several autoantibodies in the sera of patients with Psoriatic Arthritis.

\begin{tabular}{|c|c|c|c|c|}
\hline Authors & PsA patients $(N)$ & Controls $(N)$ & Autoantibodies tested & Autoantibodies positivity in PsA \\
\hline \multirow[t]{3}{*}{ Silvy et al., 2015} & 232 & $\mathrm{HC}(91)$ & ANA $^{*}$ & ANA $54 \% * *$ \\
\hline & & & $\mathrm{RF}$ & RF $15 \%$ \\
\hline & & & Anti-CCP & Anti-CCP $1.7 \%$ \\
\hline \multirow[t]{4}{*}{ Chimenti et al., 2015} & 30 & $\mathrm{HC}(40)$ & Anti-CarP & Anti-CarP $30.8 \%$ \\
\hline & & & ANA $^{*}$ & ANA $3.4 \% \S$ \\
\hline & & & $\mathrm{RF}$ & RF $6.7 \%$ \\
\hline & & & Anti-CCP & No patients with anti-CCP \\
\hline \multirow[t]{2}{*}{ Dalmády et al., 2013} & 46 & $\mathrm{PsO}(42)$ & Anti-MCV & Anti-MCV levels \\
\hline & & $\mathrm{HC}(40)$ & & Significantly higher in PsA than those in PsO \\
\hline \multirow{2}{*}{ Pasquetti et al., 2009} & 218 & None & Anti-CCP & Anti-CCP $0.9 \%$ \\
\hline & & & $\mathrm{RF}$ & No patients with RF \\
\hline \multirow[t]{2}{*}{ Inanc et al., 2007} & 56 & RA (79) & Anti-CCP & Anti-CCP $12.5 \%$ \\
\hline & & HC (39) & $\mathrm{RF}$ & RF $5.4 \%$ \\
\hline \multirow[t]{2}{*}{ Ouédraogo et al., 2007} & 102 & None & Anti-CCP & Anti-CCP $1.9 \%$ \\
\hline & & & $\mathrm{RF}$ & RF $2.9 \%$ \\
\hline \multirow[t]{3}{*}{ Alenius et al., 2006} & 160 & $\mathrm{PsO}(146)$ & Anti-CCP & Anti-CCP 7\% \\
\hline & & RA (101) & $\mathrm{RF}$ & RF $11 \%$ \\
\hline & & $\mathrm{HC}(102)$ & & \\
\hline \multirow[t]{2}{*}{ Vander Cruyssen et al., 2005} & 192 & None & Anti-CCP & Anti-CCP $7.9 \%$ \\
\hline & & & $\mathrm{RF}$ & RF $8.3 \%$ \\
\hline \multirow[t]{2}{*}{ Korendowych et al., 2005} & 126 & RA (40) & Anti-CCP & Anti-CCP $5.6 \%$ \\
\hline & & $\mathrm{HC}(40)$ & $\mathrm{RF}$ & RF $8.7 \%$ \\
\hline \multirow[t]{2}{*}{ Bogliolo et al., 2005} & 102 & None & Anti-CCP & Anti-CCP $15.7 \%$ \\
\hline & & & $\mathrm{RF}$ & RF $18.6 \%$ \\
\hline \multirow[t]{3}{*}{ Riente et al., 2004} & 75 & AS (43) & Bovine $\mathrm{tTg}(\operatorname{Ig} \mathrm{A})$ & No differences between the groups \\
\hline & & RA (79) & Human $\operatorname{tg}(\operatorname{IgA}, \operatorname{Ig} G)$ & \\
\hline & & $\mathrm{HC}(78)$ & ASCA (IgA, $\operatorname{Ig} G)$ & \\
\hline \multirow[t]{2}{*}{ Hoffmann et al., 2003} & 45 & $\mathrm{RA}(56)$ & ASCA (IgA, IgG) & No differences between the groups \\
\hline & & $\mathrm{HC}(45)$ & & \\
\hline
\end{tabular}

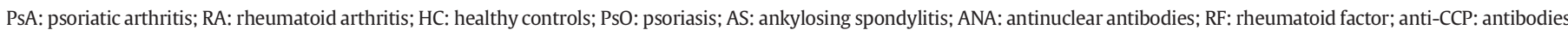
to cyclic citrullinated peptides; MCV: mutated citrullinated vimentin; tTg: anti-tissue transglutaminase antibodies; ASCA: anti-Saccharomyces cerevisiae antibodies.

* Detected by indirect immunofluorescence (IFI) on HEp-2 cells.

** At serum dilution 1:160. 
accuracy as diagnostic test to discriminate PsA patients from healthy controls [151]. In PsA patients with the highest anti-CarP levels, correlations between anti-CarP autoantibodies and the disease activity were also described [151]. Carbamylation may thus be relevant in inducing autoimmunity in PsA, and given its systemic effects, it may represent a trigger for metabolic pathways such as anaerobic cysteine metabolism and oxidative stress in PsA [183]. Authors investigated the prevalence of anti-MCV in PsA patients and reported that anti-MCV levels were significantly higher in PsA patients than those in patients with psoriasis [184]. Moreover, the presence of tender knee joints and nail psoriasis resulted significantly associated with anti-MCV positivity in the PsA group [184]. As above specified, PsA is classified among the SpA group and, given that seronegative $\mathrm{SpA}$, especially ankylosing spondylitis (AS), is shown to be associated with IBD, several studies were performed to investigate whether anti-Saccharomyces cerevisiae antibodies (ASCA), a marker for Crohn's disease (CD), were present in SpA and in the subgroups PsA, AS, undifferentiated SpA (uSpA) [185-187]. Recent evidence described an elevated serum antibody profile with respect to anti-flagellin antibodies (anti-CBir1) in AS patients without bowel symptoms suggesting that anti-CBir1 may be an indicator of subclinical bowel inflammation or predictor of future IBD in AS patients [188]. An earlier study reported ASCA IgA levels to be significantly higher in $\mathrm{SpA}$, and more specifically in AS, than in healthy controls and patients with RA representing one of the first serum marker associated with $\mathrm{SpA}$ and also a potential marker of radiological damage and a more severe AS [186]. Other authors analyzed ASCA and IgA antibodies to bovine tissue tranglutaminase (tTg) and failed to show an increased prevalence of these antibodies in patients with AS and PsA [189]. Moreover, authors described a significantly elevated prevalence of IgA antibodies to human tTg in AS patients with low 25-vitamin D3 levels suggesting that a positive human $\mathrm{tTg}$ status entails the risk of a bad vitamin D supply [190]. More recently, anti-Helicobacter pylori antibodies were detected in patients with axial SpA more frequently than in patients with CD while ASCA resulted to be more abundant in CD than in SpA [187]. Nowadays no specific markers detectable in the sera of PsA patients have been described that can improve the diagnosis and the clinical and therapeutic management of these patients. Moreover, biomarkers able to distinguish between PsA and other inflammatory arthropathies and/or psoriasis and that could be used as prognostic markers are still lacking.

\section{Conclusion}

Increasing evidence suggests that autoantibodies are associated with inflammatory arthritides including RA and "seronegative" SpA. The well-characterized autoantibodies in RA are RF and ACPA, while other novel antibodies targeting mutated proteins, such as anti-CarP, are extensively under investigation. Autoantibodies appear to improve the early diagnosis in both symptomatic and preclinical patients and may represent a tool to evaluate/predict the response to the therapy. While correlations between autoantibodies and disease course are supported by studies in humans and animal models, their pathogenicity in inflammatory arthritides needs further studies.

\section{Take-home messages}

- In susceptible individuals, under the influence of environmental factors, autoantibodies may be produced in the joints or outside in the mucosal sites such as lung and gingiva.

- The most relevant autoantibodies in rheumatoid arthritis (RA) appear to be anti-citrullinated peptide antibodies (ACPA) that recognize a variety of post-translational modified proteins, such as filaggrin, fibrinogen, vimentin, type II collagen, alpha enolase, and others.

- Several autoantibodies have been investigated and proposed as potential biomarkers to improve diagnosis and outcome in RA patients.
- Carbamylation seems to take place during inflammation when neutrophils release myeloperoxidase. The presence of anti-CarP antibodies in ACPA-negative RA patients was associated with increased disease activity and with more severe joint damage.

- Anti-CarP antibodies have been described in sera of psoriatic arthritis (PsA) patients representing the first evidence of autoantibodies in PsA. Correlations between anti-CarP levels and disease activity were also reported in PsA.

\section{Competing interests}

The authors declare they have no competing interests.

\section{Acknowledgments}

This paper is dedicated to the memory of our dear Professor Sergio Chimenti.

\section{References}

[1] Sakkas LI, Bogdanos DP, Katsiari C, Platsoucas CD. Anti-citrullinated peptides as autoantigens in rheumatoid arthritis-relevance to treatment. Autoimmun Rev 2014;13(11):1114-20.

[2] Valesini G, Gerardi MC, Iannuccelli C, Pacucci VA, Pendolino M, Shoenfeld Y. Citrullination and autoimmunity. Autoimmun Rev 2015;14(6):490-7.

[3] McInnes IB, Schett G. Cytokines in the pathogenesis of rheumatoid arthritis. Nat Rev Immunol 2007;7(6):429-42.

[4] Gianchecchi E, Fierabracci A. Gene/environment interactions in the pathogenesis of autoimmunity: new insights on the role of toll-like receptors. Autoimmun Rev 2015;14(11):971-83.

[5] Gregersen PK, Silver J, Winchester RJ. The shared epitope hypothesis. An approach to understanding the molecular genetics of susceptibility to rheumatoid arthritis. Arthritis Rheum 1987;30(11):1205-13.

[6] Huizinga TW, Amos CI, van der Helm-van Mil AH, Chen W, van Gaalen FA, Jawaheer D, et al. Refining the complex rheumatoid arthritis phenotype based on specificity of the HLA-DRB1 shared epitope for antibodies to citrullinated proteins. Arthritis Rheum 2005;52(11):3433-8.

[7] Klareskog L, Rönnelid J, Lundberg K, Padyukov L, Alfredsson L. Immunity to citrullinated proteins in rheumatoid arthritis. Annu Rev Immunol 2008;26:651-75.

[8] Auger I, Roudier C, Guis S, Balandraud N, Roudier J. HLA-DRB1*0404 is strongly associated with anticalpastatin antibodies in rheumatoid arthritis. Ann Rheum Dis 2007;66(12):1588-93.

[9] James EA, Moustakas AK, Bui J, Papadopoulos GK, Bondinas G, Buckner JH, et al. HLA-DR1001 presents "altered-self" peptides derived from joint-associated proteins by accepting citrulline in three of its binding pockets. Arthritis Rheum 2010;62(10):2909-18.

[10] Bax M, van Heemst J, Huizinga TW, Toes RE. Genetics of rheumatoid arthritis: what have we learned? Immunogenetics 2011;63(8):459-66.

[11] Hill JA, Southwood S, Sette A, Jevnikar AM, Bell DA, Cairns E. Cutting edge: the conversion of arginine to citrulline allows for a high-affinity peptide interaction with the rheumatoid arthritis-associated HLA-DRB1*0401 MHC class II molecule. J Immunol 2003;171(2):538-41.

[12] Ceccarelli F, D'Alfonso S, Perricone C, Carlomagno Y, Alessandri C, Croia C, et al. The role of eight polymorphisms in three candidate genes in determining the susceptibility, phenotype, and response to anti-TNF therapy in patients with rheumatoid arthritis. Clin Exp Rheumatol 2012;30(6):939-42.

[13] Ling S, Li Z, Borschukova O, Xiao L, Pumpens P, Holoshitz J. The rheumatoid arthritis shared epitope increases cellular susceptibility to oxidative stress by antagonizing an adenosine-mediated anti-oxidative pathway. Arthritis Res Ther 2007;9(1):R5.

[14] Ling S, Pi X, Holoshitz J. The rheumatoid arthritis shared epitope triggers innate immune signaling via cell surface calreticulin. J Immunol 2007;179(9):6359-67.

[15] De Almeida DE, Ling S, Pi X, Hartmann-Scruggs AM, Pumpens P, Holoshitz J. Immune dysregulation by the rheumatoid arthritis shared epitope. J Immunol 2010; 185(3):1927-34.

[16] Holoshitz J, Liu Y, Fu J, Joseph J, Ling S, Colletta A, et al. An HLA-DRB1-coded signal transduction ligand facilitates inflammatory arthritis: a new mechanism of autoimmunity. J Immunol 2013;190(1):48-57.

[17] van Heemst J, Hensvold AH, Jiang X, van Steenbergen H, Klareskog L, Huizinga TW, et al. Protective effect of HLA-DRB1*13 alleles during specific phases in the development of ACPA-positive RA. Ann Rheum Dis 2015 [pii: annrheumdis-2015207802].

[18] Perricone C, Ceccarelli F, Valesini G. An overview on the genetic of rheumatoid arthritis: a never-ending story. Autoimmun Rev 2011;10(10):599-608.

[19] Gregersen PK. Gaining insight into PTPN22 and autoimmunity. Nat Genet 2005; 37(12):1300-2.

[20] Stanford SM, Bottini N. PTPN22: the archetypal non-HLA autoimmunity gene. Nat Rev Rheumatol 2014;10(10):602-11.

[21] Carlton VE, Hu X, Chokkalingam AP, Schrodi SJ, Brandon R, Alexander HC, et al. PTPN22 genetic variation: evidence for multiple variants associated with rheumatoid arthritis. Am J Hum Genet 2005;77(4):567-81. 
[22] Begovich AB, Carlton VE, Honigberg LA, Schrodi SJ, Chokkalingam AP, Alexander $\mathrm{HC}$, et al. A missense single-nucleotide polymorphism in a gene encoding a protein tyrosine phosphatase (PTPN22) is associated with rheumatoid arthritis. Am J Hum Genet 2004;75(2):330-7.

[23] Ikari K, Kuwahara M, Nakamura T, Momohara S, Hara M, Yamanaka H, et al. Association between PADI4 and rheumatoid arthritis: a replication study. Arthritis Rheum 2005;52(10):3054-7.

[24] Kang CP, Lee HS, Ju H, Cho H, Kang C, Bae SC. A functional haplotype of the PADI4 gene associated with increased rheumatoid arthritis susceptibility in Koreans. Arthritis Rheum 2006;54(1):90-6.

[25] Hou S, Gao GP, Zhang XJ, Sun L, Peng WJ, Wang HF, et al. PADI4 polymorphisms and susceptibility to rheumatoid arthritis: a meta-analysis. Mod Rheumatol 2013. 23(1):50-60.

[26] Terao C, Ohmura K, Kochi Y, Ikari K, Okada Y, Shimizu M, et al. Anti-citrullinated peptide/protein antibody (ACPA)-negative RA shares a large proportion of susceptibility loci with ACPA-positive RA: a meta-analysis of genome-wide association study in a Japanese population. Arthritis Res Ther Apr 18 2015;17:104.

[27] Bossini-Castillo L, de Kovel C, Kallberg H, van 't Slot R, Italiaander A, Coenen M, et al. A genome-wide association study of rheumatoid arthritis without antibodies against citrullinated peptides. Ann Rheum Dis Mar 2015;74(3):e15.

[28] Alessandri C, Conti F, Conigliaro P, Mancini R, Massaro L, Valesini G. Seronegative autoimmune diseases. Ann N Y Acad Sci 2009;1173:52-9.

[29] Irigoyen P, Lee AT, Wener MH, Li W, Kern M, Batliwalla F, et al. Regulation of anticyclic citrullinated peptide antibodies in rheumatoid arthritis: contrasting effects of HLA-DR3 and the shared epitope alleles. Arthritis Rheum Dec 2005;52(12):3813-8.

[30] Verpoort KN, van Gaalen FA, van der Helm-van Mil AH, Schreuder GM, Breedveld FC, Huizinga TW, et al. Association of HLA-DR3 with anti-cyclic citrullinated peptide antibody-negative rheumatoid arthritis. Arthritis Rheum Oct 2005;52(10): 3058-62.

[31] Lundström E, Källberg H, Smolnikova M, Ding B, Rönnelid J, Alfredsson L, et al. Opposing effects of HLA-DRB1*13 alleles on the risk of developing anti-citrullinated protein antibody-positive and anti-citrullinated protein antibody-negative rheumatoid arthritis. Arthritis Rheum 2009;60(4):924-30.

[32] Sigurdsson S, Padyukov L, Kurreeman FA, Liljedahl U, Wiman AC, Alfredsson L, et al. Association of a haplotype in the promoter region of the interferon regulatory factor 5 gene with rheumatoid arthritis. Arthritis Rheum 2007;56(7):2202-10.

[33] Wang CJ, Yang YJ, Huang CC. The effects of shockwave on systemic concentrations of nitric oxide level, angiogenesis and osteogenesis factors in hip necrosis. Rheumatol Int 2011;31(7):871-7.

[34] Garnier S, Dieudé P, Michou L, Barbet S, Tan A, Lasbleiz S, et al. IRF5 rs2004640-T allele, the new genetic factor for systemic lupus erythematosus, is not associated with rheumatoid arthritis. Ann Rheum Dis 2007;66(6):828-31.

[35] Rueda B, Reddy MV, González-Gay MA, Balsa A, Pascual-Salcedo D, Petersson IF, et al. Analysis of IRF5 gene functional polymorphisms in rheumatoid arthritis. Arthritis Rheum 2006;54(12):3815-9.

[36] Gutierrez-Achury J, Zorro MM, Ricaño-Ponce I, Zhernakova DV, Coeliac Disease Immunochip Consortium, RACI Consortium, et al. Functional implications of disease-specific variants in loci jointly associated with coeliac disease and rheumatoid arthritis. Hum Mol Genet Jan 1 2016;25(1):180-90.

[37] Perricone C, Versini M, Ben-Ami D, Gertel S, Watad A, Segel MJ, et al. Smoke and autoimmunity: the fire behind the disease. Autoimmun Rev Apr 2016;15(4): 354-74.

[38] Perricone R, de Carolis C, de Sanctis G, Fontana L. Complement activation by cigarette smoke condensate and tobacco infusion. Arch Environ Health May-Jun 1983;38(3):176-9.

[39] Kobayashi S, Okamoto H, Iwamoto T, Toyama Y, Tomatsu T, Yamanaka H, et al. A role for the aryl hydrocarbon receptor and the dioxin TCDD in rheumatoid arthritis. Rheumatology (Oxford) Sep 2008;47(9):1317-22.

[40] Henley DV, Bellone CJ, Williams DA, Ruh TS, Ruh MF. Aryl hydrocarbon receptormediated posttranscriptional regulation of IL-1beta. Arch Biochem Biophys Feb 1 2004;422(1):42-51.

[41] Ospelt C, Camici GG, Engler A, Kolling C, Vogetseder A, Gay RE, et al. Smoking induces transcription of the heat shock protein system in the joints. Ann Rheum Dis 2014 Jul:73(7):1423-6.

[42] Pedersen M, Jacobsen S, Klarlund M, Pedersen BV, Wiik A, Wohlfahrt J, et al. Environmental risk factors differ between rheumatoid arthritis with and without autoantibodies against cyclic citrullinated peptides. Arthritis Res Ther 2006;8(4):R133.

[43] Klareskog L, Stolt P, Lundberg K, Källberg H, Bengtsson C, Grunewald J, et al. A new model for an etiology of rheumatoid arthritis: smoking may trigger HLA-DR (shared epitope)-restricted immune reactions to autoantigens modified by citrullination. Arthritis Rheum 2006;54(1):38-46.

[44] Shi J, van Veelen PA, Mahler M, Janssen GM, Drijfhout JW, Huizinga TW, et al. Carbamylation and antibodies against carbamylated proteins in autoimmunity and other pathologies. Autoimmun Rev Mar 2014;13(3):225-30.

[45] Jaisson S, Larreta-Garde V, Bellon G, Hornebeck W, Garnotel R, Gillery P. Carbamylation differentially alters type I collagen sensitivity to various collagenases. Matrix Biol 2007;26(3):190-6 [Epub 2006 Nov 10].

[46] Springer GF, Yang HJ, Desai PR, Jirgensons B. Effect of carbamylation of lysine epsilon-amino groups on the activity of blood group specific glycoproteins. Immunol Commun 1975;4(6):553-64.

[47] Sirpal S. Myeloperoxidase-mediated lipoprotein carbamylation as a mechanistic pathway for atherosclerotic vascular disease. Clin Sci (Lond) 2009;116(9):681-95.

[48] Schreier SM, Hollaus M, Hermann M, Jirovetz L, Exner M, Kapiotis S, et al. Carbamoylated free amino acids in uremia: $\mathrm{HOCl}$ generates volatile protein modifying and cytotoxic oxidant species from $\mathrm{N}$-carbamoyl-threonine but not threonine. Biochimie 2012;94(11):2441-7.
[49] Shi J, van de Stadt LA, Levarht EW, Huizinga TW, Hamann D, van Schaardenburg D, et al. Anti-carbamylated protein (anti-CarP) antibodies precede the onset of rheumatoid arthritis. Ann Rheum Dis 2014;73(4):780-3.

[50] Jiang X, Källberg H, Chen Z, Ärlestig L, Rantapää-Dahlqvist S, Davila S, et al. An immunochip-based interaction study of contrasting interaction effects with smoking in ACPA-positive versus ACPA-negative rheumatoid arthritis. Rheumatology (Oxford) 2016;55(1):149-55.

[51] Seror R, Le Gall-David S, Bonnaure-Mallet M, Schaeverbeke T, Cantagrel A, Minet J et al. Association of anti-Porphyromonas gingivalis antibody titers with nonsmoking status in early rheumatoid arthritis: results from the prospective French cohort of patients with early rheumatoid arthritis. Arthritis Rheumatol 2015;67(7):1729-37.

[52] Mikuls TR, Payne JB, Yu F, Thiele GM, Reynolds RJ, Cannon GW, et al. Periodontitis and Porphyromonas gingivalis in patients with rheumatoid arthritis. Arthritis Rheumatol 2014;66(5):1090-100.

[53] de Pablo P, Dietrich T, McAlindon TE. Association of periodontal disease and tooth loss with rheumatoid arthritis in the US population. J Rheumatol 2008;35(1):70-6.

[54] Wegner N, Wait R, Sroka A, Eick S, Nguyen KA, Lundberg K, et al. Peptidylarginine deiminase from Porphyromonas gingivalis citrullinates human fibrinogen and $\alpha-$ enolase: implications for autoimmunity in rheumatoid arthritis. Arthritis Rheum 2010;62(9):2662-72.

[55] Kharlamova N, Jiang X, Sherina N, Potempa B, Israelsson L, Quirke AM, et al. Antibodies to Porphyromonas gingivalis indicate interaction between oral infection, smoking and risk genes in rheumatoid arthritis etiology. Arthritis Rheumatol Mar 2016;68(3):604-13.

[56] Yahya A, Bengtsson C, Larsson P, Too CL, Mustafa AN, Abdullah NA, et al. Silica exposure is associated with an increased risk of developing ACPA-positive rheumatoid arthritis in an Asian population: evidence from the Malaysian MyEIRA casecontrol study. Mod Rheumatol Mar 2014;24(2):271-4.

[57] Otsuki T, Hayashi H, Nishimura Y, Hyodo F, Maeda M, Kumagai N, et al. Dysregulation of autoimmunity caused by silica exposure and alteration of Fas-mediated apoptosis in T lymphocytes derived from silicosis patients. Int J Immunopathol Pharmacol 2011;24(1 Suppl):11S-6S.

[58] Rantapää-Dahlqvist S, de Jong BA, Berglin E, Hallmans G, Wadell G, Stenlund H, et al. Antibodies against cyclic citrullinated peptide and IgA rheumatoid factor predict the development of rheumatoid arthritis. Arthritis Rheum 2003;48(10): 2741-9.

[59] Aho K, Palosuo T, Raunio V, Puska P, Aromaa A, Salonen JT. When does rheumatoid disease start? Arthritis Rheum 1985;28(5):485-9.

[60] Majka DS, Deane KD, Parrish LA, Lazar AA, Barón AE, Walker CW, et al. Duration of preclinical rheumatoid arthritis-related autoantibody positivity increases in subjects with older age at time of disease diagnosis. Ann Rheum Dis 2008;67(6): 801-7.

[61] Kokkonen H, Mullazehi M, Berglin E, Hallmans G, Wadell G, Rönnelid J, et al. Antibodies of IgG, IgA and IgM isotypes against cyclic citrullinated peptide precede the development of rheumatoid arthritis. Arthritis Res Ther 2011;13(1):R13.

[62] Nielen MM, van Schaardenburg D, Reesink HW, van de Stadt RJ, van der HorstBruinsma IE, de Koning MH, et al. Specific autoantibodies precede the symptoms of rheumatoid arthritis: a study of serial measurements in blood donors. Arthritis Rheum 2004;50(2):380-6.

[63] Brink M, Hansson M, Mathsson L, Jakobsson PJ, Holmdahl R, Hallmans G, et al. Multiplex analyses of antibodies against citrullinated peptides in individuals prior to development of rheumatoid arthritis. Arthritis Rheum 2013;65(4):899-910.

[64] Willemze A, Böhringer S, Knevel R, Levarht EW, Stoeken-Rijsbergen G, HouwingDuistermaat JJ, et al. The ACPA recognition profile and subgrouping of ACPApositive RA patients. Ann Rheum Dis 2012;71(2):268-74.

[65] van der Woude D, Rantapää-Dahlqvist S, Ioan-Facsinay A, Onnekink C, Schwarte $\mathrm{CM}$, Verpoort KN, et al. Epitope spreading of the anti-citrullinated protein antibody response occurs before disease onset and is associated with the disease course of early arthritis. Ann Rheum Dis 2010;69(8):1554-61.

[66] Stoop JN, Liu BS, Shi J, Jansen DT, Hegen M, Huizinga TW, et al. Antibodies specific for carbamylated proteins precede the onset of clinical symptoms in mice with Collagen induced arthritis. PLoS One 2014;9(7), e102163.

[67] Conigliaro P, Benson RA, Patakas A, Kelly SM, Valesini G, Holmdahl R, et al. Characterization of the anticollagen antibody response in a new model of chronic polyarthritis. Arthritis Rheum 2011;63(8):2299-308.

[68] Krabben A, Huizinga TW, van der Helm-van Mil AH. Undifferentiated arthritis characteristics and outcomes when applying the 2010 and 1987 criteria for rheumatoid arthritis. Ann Rheum Dis 2012;71(2):238-41.

[69] van Gaalen FA, Linn-Rasker SP, van Venrooij WJ, de Jong BA, Breedveld FC, Verweij $\mathrm{CL}$, et al. Autoantibodies to cyclic citrullinated peptides predict progression to rheumatoid arthritis in patients with undifferentiated arthritis: a prospective cohort study. Arthritis Rheum 2004;50(3):709-15.

[70] van Venrooij WJ, van Beers JJ, Pruijn GJ. Anti-CCP antibodies: the past, the present and the future. Nat Rev Rheumatol 2011;7(7):391-8.

[71] van Venrooij WJ, Zendman AJ, Pruijn GJ. Autoantibodies to citrullinated antigens in (early) rheumatoid arthritis. Autoimmun Rev 2006;6(1):37-41.

[72] Bos WH, Wolbink GJ, Boers M, Tijhuis GJ, de Vries N, van der Horst-Bruinsma IE et al. Arthritis development in patients with arthralgia is strongly associated with anti-citrullinated protein antibody status: a prospective cohort study. Ann Rheum Dis 2010;69(3):490-4.

[73] van de Stadt LA, van der Horst AR, de Koning MH, Bos WH, Wolbink GJ, van de Stadt RJ, et al. The extent of the anti-citrullinated protein antibody repertoire is associated with arthritis development in patients with seropositive arthralgia. Ann Rheum Dis 2011;70(1):128-33.

[74] Nam JL, Hunt L, Hensor EM, Emery P. Enriching case selection for imminent RA: the use of anti-CCP antibodies in individuals with new non-specific musculoskeletal 
symptoms - a cohort study. Ann Rheum Dis 2015 [pii: annrheumdis-2015207871].

[75] Shi J, van de Stadt LA, Levarht EW, Huizinga TW, Toes RE, Trouw LA, et al. Anticarbamylated protein antibodies are present in arthralgia patients and predict the development of rheumatoid arthritis. Arthritis Rheum 2013:65(4):911-5.

[76] Brink M, Verheul MK, Rönnelid J, Berglin E, Holmdahl R, Toes RE, et al. Anticarbamylated protein antibodies in the pre-symptomatic phase of rheumatoid arthritis, their relationship with multiple anti-citrulline peptide antibodies and association with radiological damage. Arthritis Res Ther 2015;17:25.

[77] Mjaavatten MD, van der Heijde D, Uhlig T, Haugen AJ, Nygaard H, Sidenvall G, et al The likelihood of persistent arthritis increases with the level of anti-citrullinated peptide antibody and immunoglobulin $\mathrm{M}$ rheumatoid factor: a longitudinal study of 376 patients with very early undifferentiated arthritis. Arthritis Res Ther 2010; 12(3):R76.

[78] Shi J, van Steenbergen HW, van Nies JA, Levarht EW, Huizinga TW, van der Helmvan Mil AH, et al. The specificity of anti-carbamylated protein antibodies for rheumatoid arthritis in a setting of early arthritis. Arthritis Res Ther 2015;17:339.

[79] Muller PC, Anink J, Shi J, Levarht EW, Reinards TH, Otten MH, et al. Anticarbamylated protein (anti-CarP) antibodies are present in sera of juvenile idiopathic arthritis (JIA) patients. Ann Rheum Dis 2013;72(12):2053-5.

[80] Aletaha D, Neogi T, Silman AJ, Funovits J, Felson DT, Bingham COIII, et al. 2010 rheumatoid arthritis classification criteria: an American College of Rheumatology/ European League Against Rheumatism collaborative initiative. Ann Rheum Dis 2010;69(9):1580-8.

[81] Sutton B, Corper A, Bonagura V, Taussig M. The structure and origin of rheumatoid factors. Immunol Today 2000;21(4):177-83.

[82] Bugatti S, Codullo V, Caporali R, Montecucco C. B cells in rheumatoid arthritis. Autoimmun Rev 2007;7(2):137-42.

[83] van der Helm-van Mil AH, Verpoort KN, Breedveld FC, Toes RE, Huizinga TW. Antibodies to citrullinated proteins and differences in clinical progression of rheumatoid arthritis. Arthritis Res Ther 2005;7(5):R949-58.

[84] van der Woude D, Young A, Jayakumar K, Mertens BJ, Toes RE, van der Heijde D, et al. Prevalence of and predictive factors for sustained disease-modifying antirheumatic drug-free remission in rheumatoid arthritis: results from two large early arthritis cohorts. Arthritis Rheum 2009;60(8):2262-71.

[85] Schellekens GA, de Jong BA, van den Hoogen FH, van de Putte LB, van Venrooij WJ. Citrulline is an essential constituent of antigenic determinants recognized by rheumatoid arthritis-specific autoantibodies. J Clin Invest 1998;101(1):273-81.

[86] Vossenaar ER, Radstake TR, van der Heijden A, van Mansum MA, Dieteren C, de Rooij DJ, et al. Expression and activity of citrullinating peptidylarginine deiminase enzymes in monocytes and macrophages. Ann Rheum Dis 2004;63(4):373-81.

[87] Masson-Bessière C, Sebbag M, Durieux JJ, Nogueira L, Vincent C, Girbal-Neuhauser $\mathrm{E}$, et al. In the rheumatoid pannus, anti-filaggrin autoantibodies are produced by local plasma cells and constitute a higher proportion of IgG than in synovial fluid and serum. Clin Exp Immunol 2000;119(3):544-52.

[88] Reparon-Schuijt CC, van Esch WJ, van Kooten C, Schellekens GA, de Jong BA, van Venrooij WJ, et al. Secretion of anti-citrulline-containing peptide antibody by $B$ lymphocytes in rheumatoid arthritis. Arthritis Rheum 2001;44(1):41-7.

[89] Schellekens GA, Visser H, de Jong BA, van den Hoogen FH, Hazes JM, Breedveld FC, et al. The diagnostic properties of rheumatoid arthritis antibodies recognizing a cyclic citrullinated peptide. Arthritis Rheum 2000;43(1):155-63.

[90] Levesque MC, Zhou Z, Moreland LW. Anti-cyclic citrullinated peptide testing for the diagnosis of rheumatoid arthritis and the quest for improved sensitivity and predictive value. Arthritis Rheum 2009;60(8):2211-5.

[91] Trouw LA, Mahler M. Closing the serological gap: promising novel biomarkers for the early diagnosis of rheumatoid arthritis. Autoimmun Rev 2012;12(2): $318-22$.

[92] van Beers JJ, Willemze A, Jansen JJ, Engbers GH, Salden M, Raats J, et al. ACPA finespecificity profiles in early rheumatoid arthritis patients do not correlate with clinical features at baseline or with disease progression. Arthritis Res Ther 2013 15(5):R140.

[93] Verheul MK, Fearon U, Trouw LA, Veale DJ. Biomarkers for rheumatoid and psoriatic arthritis. Clin Immunol 2015;161(1):2-10.

[94] Hassfeld W, Steiner G, Studnicka-Benke A, Skriner K, Graninger W, Fischer I, et al. Autoimmune response to the spliceosome. An immunologic link between rheumatoid arthritis, mixed connective tissue disease, and systemic lupus erythematosus. Arthritis Rheum 1995;38(6):777-85.

[95] Hassfeld W, Steiner G, Hartmuth K, Kolarz G, Scherak O, Graninger W, et al. Demonstration of a new antinuclear antibody (anti-RA33) that is highly specific for rheumatoid arthritis. Arthritis Rheum 1989;32(12):1515-20.

[96] Nell VP, Machold KP, Stamm TA, Eberl G, Heinzl H, Uffmann M, et al. Autoantibody profiling as early diagnostic and prognostic tool for rheumatoid arthritis. Ann Rheum Dis 2005;64(12):1731-6.

[97] Konig MF, Giles JT, Nigrovic PA, Andrade F. Antibodies to native and citrullinated RA33 (hnRNP A2/B1) challenge citrullination as the inciting principle underlying loss of tolerance in rheumatoid arthritis. Ann Rheum Dis 2016 [pii: annrheumdis2015-208529].

[98] Bang H, Egerer K, Gauliard A, Lüthke K, Rudolph PE, Fredenhagen G, et al. Mutation and citrullination modifies vimentin to a novel autoantigen for rheumatoid arthritis. Arthritis Rheum 2007;56(8):2503-11.

[99] Rojanasantikul P, Pattrapornpisut P, Anuruckparadorn K, Katchamart W. The performance of a point of care test for detection of anti-mutated citrullinated vimentin and rheumatoid factor in early rheumatoid arthritis. Clin Rheumatol 2014;33(7): 919-23.

[100] Lee YH, Bae SC, Song GG. Diagnostic accuracy of anti-MCV and anti-CCP antibodies in rheumatoid arthritis: a meta-analysis. Z Rheumatol 2015;74(10):911-8.
[101] Degboé Y, Constantin A, Nigon D, Tobon G, Cornillet M, Schaeverbeke T, et al. Predictive value of autoantibodies from anti-CCP2, anti-MCV and anti-human citrullinated fibrinogen tests, in early rheumatoid arthritis patients with rapid radiographic progression at 1 year: results from the ESPOIR cohort. RMD Open 2015;1(1), e000180.

[102] Svärd A, Kastbom A, Söderlin MK, Reckner-Olsson Å, Skogh T. A comparison between IgG- and IgA-class antibodies to cyclic citrullinated peptides and to modified citrullinated vimentin in early rheumatoid arthritis and very early arthritis. J Rheumatol 2011;38(7):1265-72.

[103] Cvetkovic JT, Wållberg-Jonsson S, Ahmed E, Rantapää-Dahlqvist S, Lefvert AK. Increased levels of autoantibodies against copper-oxidized low density lipoprotein, malondialdehyde-modified low density lipoprotein and cardiolipin in patients with rheumatoid arthritis. Rheumatology (Oxford) 2002:41(9):988-95.

[104] Thiele GM, Duryee MJ, Anderson DR, Klassen LW, Mohring SM, Young KA, et al. Malondialdehyde-acetaldehyde adducts and anti-malondialdehyde-acetaldehyde antibodies in rheumatoid arthritis. Arthritis Rheumatol 2015;67(3):645-55.

[105] Vehkala L, Ukkola O, Kesäniemi YA, Kähönen M, Nieminen MS, Salomaa V, et al. Plasma IgA antibody levels to malondialdehyde acetaldehyde-adducts are associated with inflammatory mediators, obesity and type 2 diabetes. Ann Med 2013; 45(8):501-10.

[106] Rolla R, Vay D, Mottaran E, Parodi M, Traverso N, Aricó S, et al. Detection of circulating antibodies against malondialdehyde-acetaldehyde adducts in patients with alcohol-induced liver disease. Hepatology 2000;31(4):878-84.

[107] Zhao J, Zhao Y, He J, Jia R, Li Z. Prevalence and significance of anti-peptidylarginine deiminase 4 antibodies in rheumatoid arthritis. J Rheumatol 2008;35(6):969-74.

[108] Halvorsen EH, Pollmann S, Gilboe IM, van der Heijde D, Landewé R, Ødegård S, et al. Serum IgG antibodies to peptidylarginine deiminase 4 in rheumatoid arthritis and associations with disease severity. Ann Rheum Dis 2008;67(3):414-7.

[109] Auger I, Balandraud N, Rak J, Lambert N, Martin M, Roudier J. New autoantigens in rheumatoid arthritis (RA): screening 8268 protein arrays with sera from patients with RA. Ann Rheum Dis 2009;68(4):591-4.

[110] Darrah E, Giles JT, Ols ML, Bull HG, Andrade F, Rosen A. Erosive rheumatoid arthritis is associated with antibodies that activate PAD4 by increasing calcium sensitivity. Sci Transl Med 2013;5(186) [186ra65].

[111] Li W, Wang W, Sun S, Sun Y, Pan Y, Wang L, et al. Autoantibodies against the catalytic domain of BRAF are not specific serum markers for rheumatoid arthritis. PLoS One 2011;6(12), e28975.

[112] Burkhardt H, Koller T, Engström A, Nandakumar KS, Turnay J, Kraetsch HG, et al. Epitope-specific recognition of type II Collagen by rheumatoid arthritis antibodies is shared with recognition by antibodies that are arthritogenic in collagen-induced arthritis in the mouse. Arthritis Rheum Sep 2002;46(9):2339-48.

[114] Rowley MJ1, Williamson DJ, Mackay IR. Evidence for local synthesis of antibodies to denatured collagen in the synovium in rheumatoid arthritis. Arthritis Rheum Dec 1987;30(12):1420-5

[115] Tarkowski A1, Klareskog L, Carlsten H, Herberts P, Koopman WJ. Secretion of antibodies to types I and II collagen by synovial tissue cells in patients with rheumatoid arthritis. Arthritis Rheum Sep 1989;32(9):1087-92.

[116] Kim WU1, Yoo WH, Park W, Kang YM, Kim SI, Park JH, et al. IgG antibodies to type II collagen reflect inflammatory activity in patients with rheumatoid arthritis. J Rheumatol Mar 2000;27(3):575-81.

[117] Mullazehi M1, Mathsson L, Lampa J, Rönnelid J. High anti-collagen type-II antibody levels and induction of proinflammatory cytokines by anti-collagen antibodycontaining immune complexes in vitro characterise a distinct rheumatoid arthritis phenotype associated with acute inflammation at the time of disease onset. Ann Rheum Dis Apr 2007;66(4):537-41.

[118] Bläss S1, Union A, Raymackers J, Schumann F, Ungethüm U, Müller-Steinbach S, et al. The stress protein BiP is overexpressed and is a major B and T cell target in rheumatoid arthritis. Arthritis Rheum Apr 2001;44(4):761-71.

[119] Shoda H, Fujio K, Shibuya M, Okamura T, Sumitomo S, Okamoto A, et al. Detection of autoantibodies to citrullinated BiP in rheumatoid arthritis patients and proinflammatory role of citrullinated BiP in collagen-induced arthritis. Arthritis Res Ther 2011;13(6):R191.

[120] Bodman-Smith MD, Corrigall VM, Berglin E, Cornell HR, Tzioufas AG, Mavragani CP, et al. Antibody response to the human stress protein $\mathrm{BiP}$ in rheumatoid arthritis. Rheumatology (Oxford) Oct 2004;43(10):1283-7.

[121] Shoda H, Fujio K, Sakurai K, Ishigaki K, Nagafuchi Y, Shibuya M, et al. Proc Natl Acad Sci U S A. 2011 Autoantigen BiP-derived HLA-DR4 epitopes differentially recognized by effector and regulatory T Cells in rheumatoid arthritis. Arthritis Rheumatol May 2015;67(5):1171-81.

[122] Jiang X, Trouw LA, van Wesemael TJ, Shi J, Bengtsson C, Källberg H, et al. Anti-CarP antibodies in two large cohorts of patients with rheumatoid arthritis and their relationship to genetic risk factors, cigarette smoking and other autoantibodies. Ann Rheum Dis Oct 2014;73(10):1761-8.

[123] Shi J, Knevel R, Suwannalai P, van der Linden MP, Janssen GM, van Veelen PA, et al. Autoantibodies recognizing carbamylated proteins are present in sera of patients with rheumatoid arthritis and predict joint damage. Proc Natl Acad Sci U S A Oct 18 2011;108(42):17372-7.

[124] Gan RW, Trouw LA, Shi J, Toes RE, Huizinga TW, Demoruelle MK, et al. Anticarbamylated protein antibodies are present prior to rheumatoid arthritis and are associated with its future diagnosis. J Rheumatol Apr 2015;42(4):572-9.

[125] Firestein GS. Evolving concepts of rheumatoid arthritis. Nature 2003;423(6937): 356-61.

[126] Besada E, Nikolaissen C, Nossent H. Should rheumatoid factor in rheumatoid arthritis be sent to Davy Jones's Locker? Scand J Rheumatol 2012;41(2):85-8.

[127] Forslind K, Ahlmen M, Eberhardt K, Hafstrom I, Svensson B. Prediction of radiological outcome in early rheumatoid arthritis in clinical practice: role of antibodies to citrullinated peptides (anti-CCP). Ann Rheum Dis 2004;63(9):1090-5. 
[128] Quinn MA, Gough AK, Green MJ, et al. Anti-CCP antibodies measured at disease onset help identify seronegative rheumatoid arthritis and predict radiological and functional outcome. Rheumatology (Oxford) 2006;45:478-80.

[129] De RL. Rheumatoid factor and anticitrullinated protein antibodies in rheumatoid arthritis: diagnostic value, associations with radiological progression rate, and extra-articular manifestations. Ann Rheum Dis 2004;63:1587-93.

[130] Shidara K, Inoue E, Hoshi D, et al. Anti-cyclic citrullinated peptide antibody predicts functional disability in patients with rheumatoid arthritis in a large prospective observational cohort in Japan. Rheumatol Int 2012;32:361-6.

[131] Humphreys JH, van Nies J, Chipping J, et al. Rheumatoid factor and anticitrullinated protein antibody positivity, but not level, are associated with increased mortality in patients with rheumatoid arthritis: results from two large independent cohorts. Arthritis Res Ther 2014;16:483.

[132] López-Longo FJ1, Sánchez-Ramón S, Carreño L. The value of anti-cyclic citrullinated peptide antibodies in rheumatoid arthritis: do they imply new risk factors? Drug News Perspect Nov 2009;22(9):543-8.

[133] Willemze A, Trouw LA, Toes RE, Huizinga TW. The influence of ACPA status and characteristics on the course of RA. Nat Rev Rheumatol Jan 31 2012;8(3):144-52.

[134] Nielen MM, van der Horst AR, van Schaardenburg D, van der Horst-Bruinsma IE, van de Stadt RJ, Aarden L, et al. Antibodies to citrullinated human fibrinogen (ACF) have diagnostic and prognostic value in early arthritis. Ann Rheum Dis Aug 2005;64(8):1199-204.

[135] Chen D, Li H, Liang L, Xiao Y, Xu T, Qiu Q et al. Clinical features and independent predictors in the further development of rheumatoid arthritis in undifferentiated arthritis. Rheumatol Int Nov 2013;33(11):2827-32.

[136] Bizzaro N, Bartoloni E, Morozzi G, Manganelli S, Riccieri V, Sabatini P, et al. Anticyclic citrullinated peptide antibody titer predicts time to rheumatoid arthritis onset in patients with undifferentiated arthritis: results from a 2-year prospective study. Arthritis Res Ther Jan 22 2013;15(1):R16.

[137] Humphreys JH, Verheul MK, Barton A, MacGregor AJ, Lunt M, Toes RE, et al. Anticarbamylated protein antibodies are associated with long-term disability and increased disease activity in patients with early inflammatory arthritis: results from the Norfolk Arthritis Register. Ann Rheum Dis Oct 62015.

[138] Alessandri C, Bartosiewicz I, Pendolino M, Mancini R, Colasanti T, Pecani A, et al. Anti-carbamylated protein antibodies in unaffected first-degree relatives of rheumatoid arthritis patients: lack of correlation with anti-cyclic citrullinated protein antibodies and rheumatoid factor. Clin Exp Rheumatol Nov-Dec 2015;33(6): 824-30.

[139] Bartoloni E, Alunno A, Bistoni O, Bizzaro N, Migliorini P, Morozzi G, et al. Diagnostic value of anti-mutated citrullinated vimentin in comparison to anti-cyclic citrullinated peptide and anti-viral citrullinated peptide 2 antibodies in rheumatoid arthritis: an Italian multicentric study and review of the literature. Autoimmun Rev Sep 2012;11(11).

[140] Mansour Howaida E, Metwaly Khaled M, Hassan Iman A, Elshamy Hebat-Allah A, Elbeblawy Moataz MS. Antibodies to mutated citrullinated vimentin in rheumatoid arthritis: diagnostic value, association with radiological damage and axial skeleton affection. Clin Med Insights Arthritis Musculoskelet Disord 2010;3:33-42.

[141] Mullazehi M, Wick MC, Klareskog L, van Vollenhoven R, Rönnelid J. Anti-type II collagen antibodies are associated with early radiographic destruction in rheumatoid arthritis. Arthritis Res Ther May 1 2012;14(3):R100.

[142] Sihvonen S, Korpela M, Laippala P, Mustonen J, Pasternack A. Death rates and causes of death in patients with rheumatoid arthritis: a population-based study. Scand J Rheumatol 2004;33(4):221-7.

[143] Turesson C, Eberhardt K, Jacobsson LT, Lindqvist E. Incidence and predictors of severe extra-articular disease manifestations in an early rheumatoid arthritis inception cohort. Ann Rheum Dis Nov 2007;66(11):1543-4.

[144] López-Longo FJ, Oliver-Miñarro D, de la Torre I, González-Díaz De Rábago E, Sánchez-Ramón S, Rodríguez-Mahou M, et al. Association between anti-cyclic citrullinated peptide antibodies and ischemic heart disease in patients with rheumatoid arthritis. Arthritis Rheum Apr 15 2009;61(4):419-24.

[145] Visser K, Verpoort KN, van Dongen H, van der Kooij SM, Allaart CF, Toes RE, et al. Pretreatment serum levels of anti-cyclic citrullinated peptide antibodies are associated with the response to methotrexate in recent-onset arthritis. Ann Rheum Dis Aug 2008;67(8):1194-5.

[146] van Dongen H, van Aken J, Lard LR, Visser K, Ronday HK, Hulsmans HM, et al. Efficacy of methotrexate treatment in patients with probable rheumatoid arthritis: a double-blind, randomized, placebo-controlled trial. Arthritis Rheum May 2007: 56(5):1424-32.

[147] de Vries-Bouwstra JK1, Goekoop-Ruiterman YP, Verpoort KN, Schreuder GM, Ewals JA, Terwiel JP, et al. Progression of joint damage in early rheumatoid arthritis: association with HLA-DRB1, rheumatoid factor, and anti-citrullinated protein antibodies in relation to different treatment strategies. Arthritis Rheum May 2008; 58(5):1293-8.

[148] Sokolove J, Schiff M, Fleischmann R, Weinblatt ME, Connolly SE, Johnsen A, et al. Impact of baseline anti-cyclic citrullinated peptide-2 antibody concentration on efficacy outcomes following treatment with subcutaneous abatacept or adalimumab: 2-year results from the AMPLE trial. Ann Rheum Dis 2016 Apr; 75(4):709-14.

[149] Gardette A, Ottaviani S, Tubach F, Roy C, Nicaise-Roland P, Palazzo E, et al. High anti-CCP antibody titres predict good response to rituximab in patients with active rheumatoid arthritis. Joint Bone Spine Oct 2014;81(5):416-20.

[150] Moll JM, Wright V. Psoriatic arthritis. Semin Arthritis Rheum 1973;3(1):55-78.

[151] Chimenti MS, Triggianese P, Nuccetelli M, Terracciano C, Crisanti A, Guarino MD, et al. Auto-reactions, autoimmunity and psoriatic arthritis. Autoimmun Rev Dec 2015;14(12):1142-6.
[152] Stolwijk C, van Onna M, Boonen A, van Tubergen A. The global prevalence of spondyloarthritis: a systematic review and meta-regression analysis. Arthritis Care Res (Hoboken) Dec 29 2015. http://dx.doi.org/10.1002/acr.22831.

[153] Acosta Felquer ML, FitzGerald O. Peripheral joint involvement in psoriatic arthritis patients. Clin Exp Rheumatol Sep-Oct 2015;33(5 Suppl 93):S26-30.

[154] Haroon M, FitzGerald O. Psoriatic arthritis: complexities, comorbidities and implications for the clinic. Expert Rev Clin Immunol Jan 2016;28:1-12.

[155] Esposito M, Giunta A, Mazzotta A, Zangrilli A, Babino G, Bavetta M, et al. Efficacy and safety of subcutaneous anti-tumor necrosis factor-alpha agents, etanercept and adalimumab, in elderly patients affected by psoriasis and psoriatic arthritis: an observational long-term study. Dermatology 2012;225(4):312-9.

[156] Versini M, Jeandel PY, Rosenthal E, Shoenfeld Y. Obesity in autoimmune diseases: not a passive bystander. Autoimmun Rev Sep 2014;13(9):981-1000.

[157] Haque N, Lories RJ, de Vlam K. Comorbidities associated with psoriatic arthritis compared with non-psoriatic spondyloarthritis: a cross-sectional study. J Rheumatol Feb 2016;43(2):376-82.

[158] Coates LC, Kavanaugh A, Mease PJ, Soriano ER, Laura Acosta Felquer M, et al. Group for research and assessment of psoriasis and psoriatic arthritis: treatment recommendations for psoriatic arthritis. Arthritis Rheumatol 2015(2016 Jan 8).

[159] Taylor W, Gladman D, Helliwell P, Marchesoni A, Mease P, Mielants H, et al. Classification criteria for psoriatic arthritis: development of new criteria from a large international study. Arthritis Rheum 2006;54(8):2665-73.

[160] Congi L, Roussou E. Clinical application of the CASPAR criteria for psoriatic arthritis compared to other existing criteria. Clin Exp Rheumatol May-Jun 2010;28(3): 304-10.

[161] Teoli M, Zangrilli A, Chimenti MS, Talamonti M, Bavetta M, Graceffa D, et al. Evaluation of clinical and ultrasonographic parameters in psoriatic arthritis patients treated with adalimumab: a retrospective study. Clin Dev Immunol 2012;2012: 823854.

[162] Kane D, Stafford L, Bresnihan B, FitzGerald O. A prospective, clinical and radiological study of early psoriatic arthritis: an early synovitis clinic experience. Rheumatology (Oxford) 2003;42:1460-8.

[163] Chimenti MS, Ballanti E, Perricone C, Cipriani P, Giacomelli R, Perricone R. Immunomodulation in psoriatic arthritis: focus on cellular and molecular pathways. Autoimmun Rev 2013;12:599-606.

[164] FitzGerald O, Haroon M, JT Giles, Winchester R. Concepts of pathogenesis in psoriatic arthritis: genotype determines clinical phenotype. Arthritis Res Ther 2015;17: 115.

[165] Cañete JD, Santiago B, Cantaert T, Sanmartí R, Palacin A, Celis R, et al. Ectopic lymphoid neogenesis in psoriatic arthritis. Ann Rheum Dis Jun 2007;66(6):720-6.

[166] Conigliaro P, Triggianese P, Perricone C, Chimenti MS, Di Muzio G, Ballanti E, et al. Restoration of peripheral blood natural killer and B cell levels in patients affected by rheumatoid and psoriatic arthritis during etanercept treatment. Clin Exp Immunol 2014; 177:234-43.

[167] van Kuijk AW, Tak PP. Synovitis in psoriatic arthritis: immunohistochemistry comparisons with rheumatoid arthritis, and effects of therapy. Curr Rheumatol Rep Aug 2011;13(4):353-9.

[168] Bandinelli F, Denaro V, Prignano F, Collaku L, Ciancio G, Matucci-Cerinic M. Ultrasonographic wrist and hand abnormalities in early psoriatic arthritis patients: correlation with clinical, dermatological, serological and genetic indices. Clin Exp Rheumatol May-Jun 2015;33(3):330-5.

[169] Korendowych E, Owen P, Ravindran J, Carmichael C, McHugh N. The clinical and genetic associations of anti-cyclic citrullinated peptide antibodies in psoriatic arthritis. Rheumatology (Oxford) Aug 2005;44(8):1056-60.

[170] Pasquetti P, Morozzi G, Galeazzi M. Very low prevalence of anti-CCP antibodies in rheumatoid factor-negative psoriatic polyarthritis. Rheumatology (Oxford) Mar 2009;48(3):315-6.

[171] Inanc N, Dalkilic E, Kamali S, Kasapoglu-Günal E, Elbir Y, Direskeneli H, et al. AntiCCP antibodies in rheumatoid arthritis and psoriatic arthritis. Clin Rheumatol Jan 2007;26(1):17-23.

[172] Bogliolo L, Alpini C, Caporali R, Scirè CA, Moratti R, Montecucco C. Antibodies to cyclic citrullinated peptides in psoriatic arthritis. J Rheumatol Mar 2005;32(3):511-5

[173] Ouédraogo DD, Palazzo E, Nicaise-Roland P, Somogyi N, Grootenboer-Mignot S Hayem G, et al. Anti-cyclic citrullinated peptide antibodies (CCP2) in patients with psoriatic arthritis. Clin Exp Rheumatol Nov-Dec 2007;25(6):930-1.

[174] Alenius GM, Berglin E, Rantapää Dahlqvist S. Antibodies against cyclic citrullinated peptide (CCP) in psoriatic patients with or without joint inflammation. Ann Rheum Dis Mar 2006;65(3):398-400.

[175] Vander Cruyssen B, Hoffman IE, Zmierczak H, Van den Berghe M, Kruithof E, De Rycke L, et al. Anti-citrullinated peptide antibodies may occur in patients with psoriatic arthritis. Ann Rheum Dis Aug 2005;64(8):1145-9.

[176] Silvy F, Bertin D, Bardin N, Auger I, Guzian MC, Mattei JP, et al. Antinuclear antibodies in patients with psoriatic arthritis treated or not with biologics. PLoS One Jul 31 2015;10(7), e0134218.

[177] Hoffmann JH, Hartmann M, Enk AH, Hadaschik EN. Autoantibodies in psoriasis as predictors for loss of response and anti-infliximab antibody induction. $\mathrm{Br} \mathrm{J}$ Dermatol Dec 2011;165(6):1355-8.

[178] Saraceno R, Specchio F, Torres T, Nisticò SP, Rizza S, Chimenti S. The role of antinuclear autoantibodies in patients with psoriasis treated with anti-tumor necrosis factor-alpha agents: a retrospective long-term study. J Am Acad Dermatol May 2012;66(5):e180-2.

[179] Saraceno R, Chimenti MS, Chimenti S. The significance of the development of antinuclear antibodies during infliximab treatment. J Am Acad Dermatol Aug 2013; 69(2):314.

[180] Hoxha A, Calligaro A, Tonello M, Ramonda R, Carletto A, Paolazzi G, et al. The clinical relevance of early anti-adalimumab antibodies detection in rheumatoid 
arthritis, ankylosing spondylitis and psoriatic arthritis: A prospective multicentre study. Joint Bone Spine Dec 292015 [pii: S1297-319X(15)00253-5].

[181] Dolcino M, Lunardi C, Ottria A, Tinazzi E, Patuzzo G, et al. Crossreactive autoantibodies directed against cutaneous and joint antigens are present in psoriatic arthritis. PLoS One 2014;9, e115424.

[182] Dolcino M, Ottria A, Barbieri A, Patuzzo G, Tinazzi E, Argentino G, et al. Gene Expression Profiling in peripheral blood cells and synovial membranes of patients with psoriatic arthritis. PLoS One 2015;10(6), e0128262.

[183] Sokolowska M, Niedzielska E, IciekM Bilska A, Lorenc-Koci E, Wlodek L. The effect of the uremic toxin cyanate (CNO-) on anaerobic cysteine metabolism and oxidative processes in the rat liver: a protective effect of lipoate. Toxicol Mech Methods 2011;21:473-8.

[184] Dalmády S, Kiss M, Képíró L, Kovács L, Sonkodi G, Kemény L, et al. Higher levels of autoantibodies targeting mutated citrullinated vimentin in patients with psoriatic arthritis than in patients with psoriasis vulgaris. Clin Dev Immunol 2013;2013: 474028.

[185] Hoffman IE, Demetter P, Peeters M, De Vos M, Mielants H, Veys EM, et al. AntiSaccharomyces cerevisiae IgA antibodies are raised in ankylosing spondylitis and undifferentiated spondyloarthropathy. Ann Rheum Dis May 2003;62(5): 455-9.
[186] Aydin SZ, Atagunduz P, Temel M, Bicakcigil M, Tasan D, Direskeneli H. Anti-Saccharomyces cerevisiae antibodies (ASCA) in spondyloarthropathies: a reassessment. Rheumatology (Oxford) Feb 2008;47(2):142-4.

[187] Rodrigues IK, Andrigueti M, de Oliveira Gil ID, de Lucca Schiavon L, de Andrade KR, Pereira IA, et al. An investigation into the relationship between anti-Helicobacter pylori and anti-Saccharomyces cerevisiae antibodies in patients with axial spondyloarthritis and Crohn disease. Rheumatol Int Feb 2015;35(2):359-66.

[188] Wallis D, Asaduzzaman A, Weisman M, Haroon N, Anton A, McGovern D, et al. Elevated serum anti-flagellin antibodies implicate subclinical bowel inflammation in ankylosing spondylitis: an observational study. Arthritis Res Ther 2013;15(5): R166.

[189] Riente L, Chimenti D, Pratesi F, Delle Sedie A, Tommasi S, Tommasi C, et al. Antibodies to tissue transglutaminase and Saccharomyces cerevisiae in ankylosing spondylitis and psoriatic arthritis. J Rheumatol May 2004;31(5):920-4.

[190] Teichmann J, Voglau MJ, Lange U. Antibodies to human tissue transglutaminase and alterations of vitamin D metabolism in ankylosing spondylitis and psoriatic arthritis. Rheumatol Int Nov 2010;30(12):1559-63. 